\title{
Fabrikasi Magnet Permanen Bonded NdFeB untuk Prototipe Generator
}

\author{
Nanang Sudrajat* dan Tony Kristiantoro \\ Pusat Penelitian Elektronika dan Telekomunikasi - LIPI \\ Jl. Cisitu 21/ 154D, Bandung 40135
}

Intisari

Magnet permanen bonded dibuat dengan mencampurkan bahan serbuk magnet Neodymium besi Boron (NdFeB) komersil type MQP 16-7 dengan bahan polimer serbuk phenol formaldehyde (bakelite) dan serbuk resin pvc. Perbandingan komposisi antara serbuk NdFeB dan polimer divariasikan pada 80: 20, 90: 10 dan 95: 5 masing-masing \% berat. Campuran ini kemudian dikompaksi dengan sistem hot press. Sifat magnet dikarakterisasi dengan menggunakan Permagraph Magnet Physik Germany. Nilai terbaik diperoleh untuk komposisi 95 : $5 \%$ berat dengan nilai $\mathrm{B}_{r}=6,04 \mathrm{kG}$, nilai $\mathrm{H}_{c}=5,883 \mathrm{kOe}, \mathrm{Bh}_{\max }=6,29 \mathrm{MGOe}$. Fabrikasi dilakukan dengan ukuran magnet $\mathrm{d}=5 \mathrm{~cm}, \mathrm{t}=0,8 \mathrm{~cm}$ dan diaplikasikan pada prototipe generator.

\begin{abstract}
Bonded permanent magnets are made by mixing a magnetic powder material Neodymium Iron Boron (Nd$\mathrm{FeB}$ ) commercial MQP type 16-7 with a polymer material powder phenol formaldehyde (Bakelite) and pvc resin powder. Comparison between the composition of $\mathrm{NdFeB}$ powder and the polymer was varied at 80: 20, 90: 10 and 95: 5 wt\% respectively. This mixture is then pressed with a hot press system. Magnetic properties were characterized by using Permagraph Magnet Physik Germany. The best value obtained for the composition of 95: $5 \%$ by weight to the value of $\mathrm{B}_{r}=6.04 \mathrm{~kg}$, the value $\mathrm{H}_{c}=5.883 \mathrm{Koe}, \mathrm{Bh}_{\max }=6.29 \mathrm{MGOe}$. Fabrication is done by the size of the magnetic $\mathrm{d}=5 \mathrm{~cm}, \mathrm{t}=0.8 \mathrm{~cm}$ and was applied to the prototype generator.
\end{abstract}

KATA KUNCI: permanent magnet, bonded magnet, neodymium iron boron, generator

\section{PENDAHULUAN}

Perkembangan material magnet permanen sangat cepat sejak 1900-an hingga saat ini, diikuti dengan semakin meningkatnya karakteristik magnet yang dihasilkan (Gambar 1).

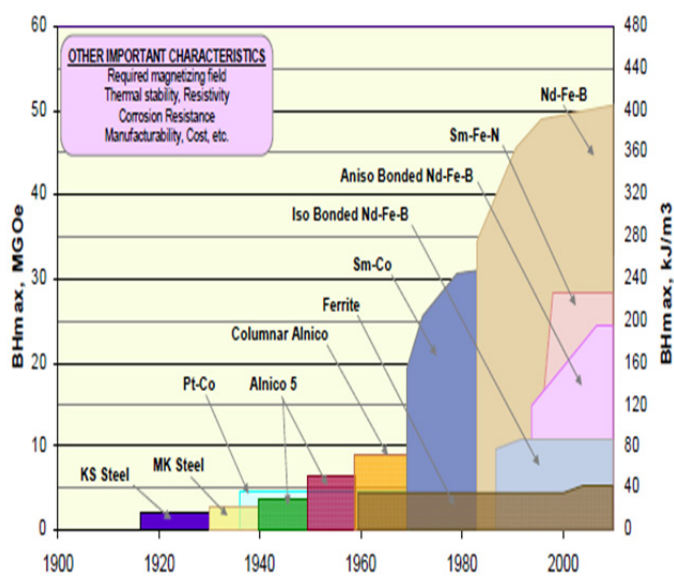

Gambar 1: Perkembangan magnet permanen [1]

\footnotetext{
*E-MAIL: nanang@ppet.lip.go.id
}

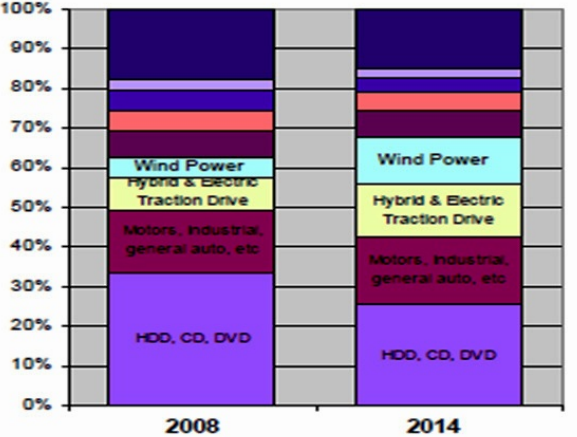

Gambar 2: Kebutuhan magnet permanen [1]

Karakteristik magnet permanen yang paling tinggi saat ini adalah Neodymium Iron Boron $(\mathrm{NdFeB})$, yang memiliki nilai produk energi maksimum sampai dengan $400 \mathrm{kJm}^{3}$. Sedangkan NdFeB bonded memiliki nilai produk energy maksimum sampai dengan $200 \mathrm{kJm}^{3}$. Kebutuhan akan magnet permanen khususnya $\mathrm{NdFeB}$ setiap tahun semakin meningkat terutama untuk kebutuhan hardware komputer dan energi khususnya wind power seperti pada Gambar 2.

Di Indonesia, energi baru dan terbarukan juga menjadi prioritas bidang energi untuk menggantikan energi yang berasal dari bahan fosil seperti BBM dan batubara. Pembangkit Listrik Tenaga Angin (PLTAg) menjadi salah satu bidang 
energi yang sedang dikembangkan terutama di Indonesia bagian timur sebagai lumbung angin di Indonesia.

Dalam sebuah sistem pembangkit listrik, generator merupakan salah satu komponen utama dimana sistem kerjanya tergantung kepada magnet permanen. Fungsi magnet pada generator adalah untuk mengubah energi mekanik menjadi energi listrik. Magnet adalah sumber energi lain yang sering dilupakan orang, padahal energi yang dihasilkan cukup tinggi dan tanpa efek pencemaran lingkungan. Sampai saat ini, kebutuhan magnet selalu diimport dari manca negara untuk berbagai kebutuhan komponen elektronik salah satunya generator.

Pada penelitian ini, dicoba untuk mengaplikasikan magnet bonded $\mathrm{NdFeB}$ pada sebuah prototipe generator untuk turbin tenaga angin (wind energy). Magnet bonded $\mathrm{NdFeB}$ adalah magnet yang dibuat dengan cara mencampurkan bahan serbuk magnet permanen dengan polimer sebagai pengikatnya. Serbuk magnet yang digunakan adalah serbuk magnet komersil NdFeB Crashed ribbon type 16-7 yang produk magnequench, sedangkan polimer yang digunakan adalah bakelit dan pvc resin. Komposisi antara serbuk magnet dan polimer divariasikan untuk mendapatkan hasil terbaik. Hasil campuran serbuk magnet dan bahan polimer kemudian dikompaksi dengan menggunakan teknik hot press. Sampel hasil kompaksi kemudian dikarakterisasi dan diukur untuk mengetahui sifat magnet dan kuat medan magnet.

\section{TEORI}

Generator untuk turbin angin sudah mulai banyak dikembangkan dengan bentuk double disk dengan bobot yang sangat ringan untuk diputarkan walaupun dengan kecepatan angin yang rendah [2].

Generator dapat didesain untuk bekerja pada putaran tertentu dengan tegangan tertentu. Tegangan induksi yang dihasilkan oleh generator dapat dihitung dengan persamaan [3]:

$$
E_{r m s}=\frac{E_{\max }}{\sqrt{2}}=\frac{2 \pi}{\sqrt{2}} \times N \times f \times \Phi_{\max } \times \frac{N_{s}}{N_{p h}}
$$

dengan $\mathrm{E}_{r m s}=$ tegangan induksi (Volt), $\mathrm{N}=$ jumlah lilitan per kumparan, $\mathrm{f}=$ frekwensi $(\mathrm{Hz}), \Phi_{\max }=$ fluks magnet $(\mathrm{Wb})$, $\mathrm{N}_{s}=$ jumlah kumparan, $\mathrm{N}_{p h}=$ jumlah fasa.

$$
\Phi_{\text {max }}=A_{\text {magn }} B_{\text {max }}
$$

$\mathrm{A}_{\text {magn }}=$ area magnet, $\mathrm{B}_{\max }=$ densitas fluks maksimum

$$
A_{\text {magn }}=\frac{\pi\left(r_{\circ}^{2}-r_{i}^{2}\right)-\tau_{f}\left(r_{\circ}-r_{i}\right) N_{m}}{N_{m}}
$$

$\mathrm{r}_{\circ}=$ radius luar magnet, $\mathrm{r}_{i}=$ radius dalam magnet, $\tau_{f}=\mathrm{jarak}$ antar magnet, $\mathrm{N}_{m}$ = jumlah magnet

$$
B_{\max }=B_{r} \frac{I_{m}}{I_{m}+\delta}
$$

$\mathrm{B}_{r}=$ densitas fluks magnet, $\mathrm{L}_{m}=$ panjang magnet, $\delta=$ jarak antara rotor dengan stator.

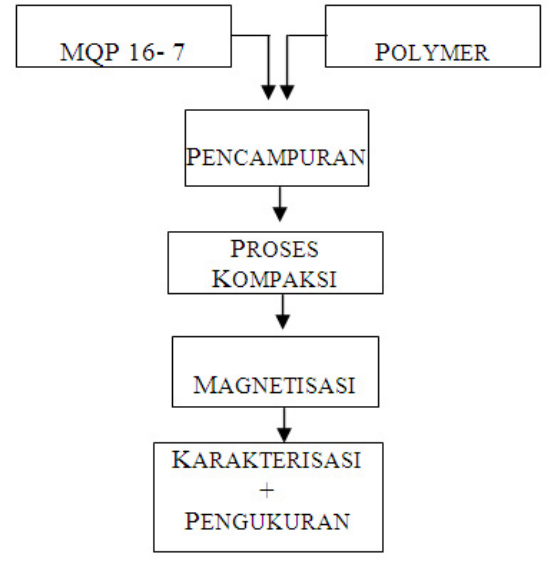

Gambar 3: Metoda pembuatan magnet bonded

\section{METODOLOGI}

Metoda pembuatan magnet bonded $\mathrm{NdFeB}$ diperlihatkan seperti pada Gambar 3. Serbuk magnet MQP 16-7 dicampur dengan bahan polimer dengan variasi komposisi $80: 20$, 90 : 20 dan 95 : 5 masing-masing \% berat. Hasil pencampuran kemudian dikompaksi menggunakan teknik hot press [4]. Kompaksi dengan teknik hot press dipilih karena dengan proses yang bersamaan antara kompaksi dan pemanasan maka polimer akan lebih cepat mengikat serbuk magnet MQP 16-7 sehingga akan diperoleh hasil kompaksi yang solid dengan densitas yang tinggi, dimana proses ini akan berpengaruh kepada sifat magnet dan kuat medannya. Kompaksi dilakukan dengan memberikan gaya 2,5 ton per satuan luas, dengan temperatur heater sebesar $200^{\circ} \mathrm{C}$ dan ditahan selama 10 menit. Perlakuan ini diberikan untuk memastikan bahwa pengikatan serbuk magnet MQP 16-7 oleh polimer sebagai binder terjadi secara optimal. Sampel hasil kompaksi magnet bonded akan mempunyai kepresisian dimensi [5], kemudian dimagnetisasi dengan memberikan energi maksimal sampai sampel mencapai titik jenuh dan dikarakterisasi untuk mendapatkan besaran-besaran induksi remanen $\left(\mathrm{B}_{r}\right) \mathrm{kG}$, koersifitas $\left(\mathrm{H}_{c}\right)$ $\mathrm{kOe}$, produk energi maksimum $\left(\mathrm{BH}_{\max }\right)$ MGOe. Langkah terakhir adalah dengan mengukur kuat medan magnet $\left(\mathrm{B}_{r}\right)$ menggunakan Gaussmeter.

\section{HASIL DAN PEMBAHASAN}

Dari hasil percobaan, didapat data karakteristik magnet pada Tabel 1 yang menggunakan bahan polimer bakelit dan data pada Tabel 2 yang menggunakan bahan polimer resin serbuk dengan metoda hot press.

Dari Tabel 1 dan 2, diperoleh trend yang sama yaitu dengan penambahan jumlah persen serbuk magnet MQP 16-7, nilai residual flux density $\left(\mathrm{B}_{r}\right)$ akan bertambah besar. Residual flux density adalah kemampuan benda magnet untuk mempertahankan energi yang diberikan dari luar. Pada eksperimen dengan karakterisasi menggunakan permagraph magnets physik diperoleh nilai terbesar yaitu 6,04 kG. Pada Gam- 
TABEL I: Pengaruh variasi bahan polymer bakelit terhadap karakteristik magnet bonded.

\begin{tabular}{lccc}
\hline \hline Sifat & \multicolumn{3}{c}{ KOMPOSISI $(\%)$} \\
Magnet & $(80: 20)$ & $(90: 10)$ & $(95: 5)$ \\
\hline & 3,2 & 5,18 & 5,96 \\
$\mathrm{~B}_{r}(\mathrm{kG})$ & 5,95 & 5,73 & 5,73 \\
$\mathrm{H}_{c}(\mathrm{kOe})$ & 2,09 & 4,4 & 5,47 \\
Bhmax $(\mathrm{MGOe})$ & & \\
Density $\left(\mathrm{g} / \mathrm{cm}^{3}\right)$ & 3,86 & 4,95 & 5,3 \\
\hline \hline
\end{tabular}

TABEL II: Pengaruh variasi bahan polymer resin terhadap karakteristik magnet bonded.

\begin{tabular}{lccc}
\hline \hline Sifat & \multicolumn{3}{c}{ KOMPOSISI (\%) } \\
Magnet & $(80: 20)$ & $(90: 10)$ & $(95: 5)$ \\
\hline & 3,07 & 5,07 & 6,04 \\
$\mathrm{~B}_{r}(\mathrm{kG})$ & 6,03 & 5,9 & 5,883 \\
$\mathrm{H}_{c}(\mathrm{kOe})$ & 1,46 & 4,57 & 6,29 \\
Bhmax $(\mathrm{MGOe})$ & 1,46 & \\
Density $\left(\mathrm{g} / \mathrm{cm}^{3}\right)$ & 3,71 & 4,75 & 5,36 \\
\hline \hline
\end{tabular}

bar 4 ditunjukkan aplikasi magnet permanen yang ditempatkan di dalam generator.

Generator mempunyai dua buah rotor saling berhadapan dengan jumlah magnet masing-masing 12 buah magnet, dan mempunyai stator 3 phase yang diapit oleh 2 buah rotor. Pengukuran generator hanya dilakukan pada 1 phase stator, pengukuran yang dilakukan adalah hubungan putaran (RPM) terhadap tegangan yang dihasilkan tanpa beban seperti yang dapat dilihat pada Tabel 3.

Dari Tabel 3 dapat dilihat bahwa potensi tegangan 1 phase sudah dapat dimanfaatkan pada putaran 300 yaitu sebesar 7,2 volt untuk pengisian accu 6 volt, dengan kapasitas stator dengan diameter kawat $1 \mathrm{~mm}$ mempunyai kapasitas arus rata-rata 1,2 ampere sehingga potensi daya terbesar pada $500 \mathrm{rpm}$ dapat menghasilkan daya sekitar 14,64 watt. Apabila potensi angin per hari sekitar 10 jam, maka generator dapat menghasilkan sekitar 146,4 watt jam.

\section{SIMPULAN}

Dari hasil penelitian pembuatan magnet bonded dengan menggunakan bahan polimer yang bervariasi, dapat disim-
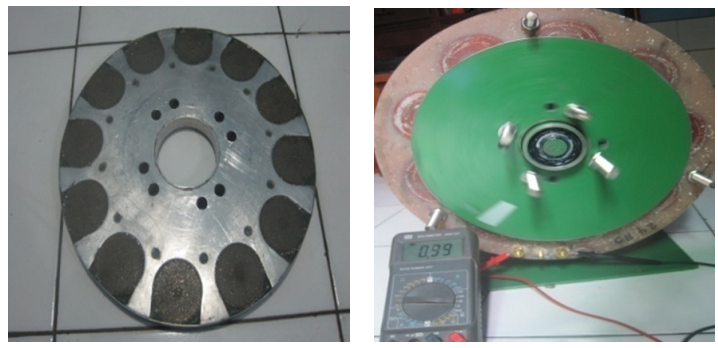

Gambar 4: Magnet bonded pada rotor

TABEL III: Pengukuran RPM dan tegangan tanpa beban.

\begin{tabular}{lc}
\hline \hline $\begin{array}{l}\text { Putaran } \\
\text { (RPM) }\end{array}$ & Tegangan \\
& Tanpa Beban \\
& (Volt)- 1 phase \\
\hline
\end{tabular}

\begin{tabular}{lc}
50 & 0,8 \\
100 & 1,9 \\
150 & 3,4 \\
200 & 4,7 \\
250 & 6 \\
300 & 7,2 \\
350 & 8,5 \\
400 & 9,6 \\
450 & 10,8 \\
500 & 12,2 \\
\hline \hline
\end{tabular}

pulkan bahwa bahan polimer resin dengan komposisi perbandingan $95 \% \mathrm{NdFeB}$ dan $5 \%$ Resin dapat menghasilkan karakteristik magnet yang paling baik dengan nilai $\mathrm{B}_{r}=6,04$ $\mathrm{kG}, \mathrm{H}_{c}=5,883 \mathrm{KOe}, \mathrm{Bh}_{\max }=6,29$ MGOe dan densitas 5,36 $\mathrm{gcm}^{-3}$. Aplikasi magnet bonded hasil percobaan pada generator magnet permanen menghasilkan potensi daya sebesar 146,4 watt untuk 10 jam.

\section{Ucapan Terima Kasih}

Penelitian ini didanai dari DIPA Tematik PPETI - LIPI 2011.

tas Teknik UI

[4] N. Idayanti, Jurnal Elektronika dan Telekomunikasi, 9, 64-68 (2009).

[5] http://www.mqitechnology.com/motor-designs.jsp 